\title{
Towards an Information Society: The State of the Arab Countries
}

\author{
Abdoulaye Kaba ${ }^{1, *}$, Raed Said ${ }^{2}$ \\ ${ }^{1}$ Al-Ain University of Science \& Technology, Al-Ain, United Arab Emirates \\ ${ }^{2}$ College of Business Administration, Al-Ain University of Science \& Technology, Al-Ain, United Arab Emirates
}

\begin{abstract}
The purpose of this paper is to explore how the Arab countries are progressing in developing information society and how they differ in their efforts to build an information society. The researchers are interested to know if there is any relationship between ICT Development Index (IDI) and ICT Price Basket (IPB), as well as the relationship between Gross National Index (GNI) and IDI. The study adopted IDI, GNI, and IPB indicators used by the International Teleco mmunication Un it (ITU) in 2011. The researchers divided the Arab countries into four groups: GCC, Levant, Magreb, and other Arab countries. Findings indicate a significant progress of the Arab countries, particularly the GCC countries, in developing information society. Results of the study show that countries with relatively high ICT price have relatively low levels of ICT access and use. Similarly, the analysis of the study found that a high GNI for a country results in a high ICT Develop ment Index and vice versa.
\end{abstract}

Keywords Information Society, Information Technology, ICT Develop ment, Arab Countries

\section{Introduction}

The use of the term 'information society' may be traced back to 1959 when Drucker first mentioned "knowledge worker"'[1]. Machlup also made a serious attempt to describe information society in the US by investigating production and distribution of knowledge[2]. Similar studies were found in Europe by studying a shift from goods-based society to information-based society[3]. Earlier literature show no clear definition for the term "information society"[1],[4-6]. Today, most of the scholars and policy makers believe that the advent of information and commun ication technologies play an important role in building and developing information society[1],[5],[7].

An information society is "a society where work, economic transactions, commun ications, information sharin $\mathrm{g}$, developing relationships, and interactions involving individuals, organizations, governments, and communities are conducted via in formation and communication technolo gy (ICT)" $[1, \mathrm{p} .70]$. The concept implies an assumption that information society is different from other types of societies[4].

Following the steps of developed countries, developing nations place high considerations on ICT in build ing in form ation society and the Arab countries are no exceptions.

* Corresponding author:

kaba_abdoulaye@yahoo.com (Abdoulaye Kaba)

Published online at http://journal.sapub.org/ijis

Copyright (C) 2012 Scientific \& Academic Publishing. All Rights Reserved
Policies of governments through the websites of the ministries, speeches and reports in the Arab world emphasize on developing strategies to become a better information society [8],[9]. For instance, a report by Al-Sudairy in 2010 shows that all the GCC countries have their national ICT strategies and are in the process of establishing the necessary legislative structure to modernize and develop ICT in the government sectors, research and development, education, health and commerce[10].

Table 1. Grouping Arab Countries into Sub-regions*

\begin{tabular}{|c|c|}
\hline Sub-region & Country \\
\hline \multirow{4}{*}{ GCC } & Bahrain \\
\cline { 2 - 2 } & Qatar \\
\cline { 2 - 2 } & Oman \\
\cline { 2 - 2 } & Saudi Arabic \\
\cline { 2 - 2 } & United Arab Emirates \\
\hline \multirow{4}{*}{ LEVANT } & Jordan \\
\cline { 2 - 2 } & Lebanon \\
\cline { 2 - 2 } & Syria \\
\hline \multirow{4}{*}{ MAGREB } & Yemen \\
\cline { 2 - 2 } & Algeria \\
\cline { 2 - 2 } & Egypt \\
\cline { 2 - 2 } & Mauritania \\
\cline { 2 - 2 } & Morocco \\
\hline \multirow{5}{*}{ OTHERS } & Tunisia \\
\cline { 2 - 2 } & Comoro Island \\
\hline \multirow{2}{*}{} & Djibouti \\
\hline
\end{tabular}

* Arab countries not included in any of the sub-regions, such as Kuwait, Sudan, and Libya are excluded due to the lack of data in the ITU report, 2011.

The main purpose of this paper is to examine, analyze and report the progress of the Arab countries in developing 
information society. For this purpose the International Telecommunication (ITU) report entitled "Measuring information society 2011 " was used and provided sufficient facts and information. For the purpose of comparisons, we divided the Arab countries into four sub-regions as listed in Table 1 .

The study attempts to investigate the following hypotheses:

H1. There are no differences among sub-regions

of the Arab countries in regard to the ICT Price

basket (IPB).

$\mathrm{H} 2$. There are no significant differences among

sub-regions of the Arab countries in regard to the

level of ICT access and use.

H3. There is no relationship between ICT Development index and ICT Price Basket of the Arab countries.

H4. There is no relationship between GNI and ICT

Develop ment Index of the Arab countries.

The paper elucidates the nature of commitment of the Arab countries towards developing information society. Results of the study may help understand current efforts and success of the Arab nations in developing information society.

\section{ICT Development Index (IDI) and ICT Price Basket (IPB)}

The report of International Telecommunication (ITU) entitled "Measuring information society 2011" features two key benchmarking tools to measure an information society: the ICT Development Index (IDI) and the ICT Price Basket (IPB). The IDI captures the level of ICT developments in 152 countries and compares progress made during the past ten years. On the other hand, the IPB combines fixed telephone, mobile cellular and fixed broadband Internet tariffs of 165 countries into one measure and compares them across countries and over time.

The IDI and IPB are important in determin ing the progress of the countries in developing information society. This study is needed for setting-up baseline figures and benchmarks in measuring progress towards developing information society in the Arab world. The sub-regions of the Arab countries with their ranks in the ITU report are presented in Table 4.

ICT Development Index (IDI) is a useful tool to benchmark and track the overall progress of countries towards information society. The IDI is a composite index made up of 11 indicators covering ICT access, use and skills as shown in Table 2. It has been constructed to measure the level and evolution over time of ICT developments, taking into consideration, in this study, the situations of the sub-regions of the Arab countries.

ICT is one of the most important indicators for the economic gro wth. In the case of the Arab countries, the ICT usage has been linked to economic factors[7]. As a comprehensive benchmarking tool, the IPB monitors the relative price of ICT services and provides indications of how affordable are services across countries and over time. The IPB indicators used in this study are presented in Table 3.

Table 2. ICT Development Index (IDI) indicators

\begin{tabular}{|c|}
\hline ICT Access \\
\hline $\begin{array}{c}\text { 1.Fixed-telephone lines per 100 inhabitants } \\
\text { 2.Mobile-cellular telephone subscript ions per 100 } \\
\text { inhabit ants }\end{array}$ \\
\hline 3.International Internet bandwidth (bit/s) per Internet user \\
\hline 4.Percentage of households with a computer \\
\hline 5.Percentage of households with Internet access \\
\hline IC T Use \\
\hline 6.Percentage of individuals using the Internet \\
\hline per 100 inhab. \\
\hline 8. Active mobile-broadband subscriptions per \\
100 inhabit ants. \\
ICT Skills \\
\hline 9.Adult literacy rate \\
\hline 10.Secondary gross enrolment ratio \\
\hline 11.T ert iary gross enrolment ratio \\
\hline
\end{tabular}

Source: International Telecommunication Union (ITU) Report, 2011.

Table 3. ICT Price Basket (IPB) indicators

\begin{tabular}{|c|}
\hline 1.ICT Price Basket \\
\hline 2.Fixed-telephone sub-basket \\
\hline 3.Mobile-cellular sub-basket \\
\hline 4.Fixed-broad band sub-basket \\
\hline
\end{tabular}

Source: International Telecommunication Union (ITU) Report, 2011.

\section{Findings and Discussion}

This section discusses IDI ranking for the Arab countries, fixed-telephone, mobile-cellular, fixed broadband of the Arab countries in 2008 and 2010. It also presents and tests four hypotheses stated in the introduction.

\subsection{IDI Ranking of the Arab Countries}

The Arab countries differ in the IDI values. These differences can be attributed to the income levels of each individual country. The values of the IDI in the Arab countries are ranging widely between 1.8 and 6.19; from which we observed that countries with high-income are on the top among the other Arab countries. More details about the ranking of IDI in the Arab countries are presented in Table 4. This table shows that the overall average of IDI has increased from 3.04 in 2008 to 3.57 in 2010 . Precisely we found that both Mauritania and Djibouti lost five positions in 2010 IDI ranking as compared to 2008 figures. On the other hand, Morocco, Oman and Saudi Arabia recorded the highest progress in ranking between 8 to 10 positions. 
Table 4. ICT Development Index (IDI) ranks for the Arab countries, 2008-2010

\begin{tabular}{|c|c|c|c|c|c|c|}
\hline Country & $\begin{array}{c}\text { Regional Rank } \\
\mathbf{2 0 1 0}\end{array}$ & $\begin{array}{c}\text { Global Rank } \\
\mathbf{2 0 1 0}\end{array}$ & IDI 2010 & $\begin{array}{c}\text { Global Rank } \\
\mathbf{2 0 0 8}\end{array}$ & IDI 2008 & $\begin{array}{c}\text { Global Rank Change } \\
\mathbf{2 0 0 8 - 2 0 1 0}\end{array}$ \\
\hline UAE & 1 & 32 & 6.19 & 32 & 5.63 & 0 \\
\hline Qatar & 2 & 44 & 5.60 & 48 & 4.50 & 4 \\
\hline Bahrain & 3 & 45 & 5.57 & 42 & 5.16 & -3 \\
\hline Saudi Arabia & 4 & 46 & 5.42 & 55 & 4.13 & 9 \\
\hline Oman & 5 & 60 & 4.38 & 68 & 3.45 & 8 \\
\hline Jordan & 6 & 73 & 3.83 & 73 & 3.29 & 0 \\
\hline Lebanon & 7 & 79 & 3.57 & 77 & 3.12 & -2 \\
\hline Tunisia & 8 & 84 & 3.43 & 82 & 2.98 & -2 \\
\hline Morocco & 9 & 90 & 3.29 & 100 & 2.60 & 10 \\
\hline Egypt & 10 & 91 & 3.28 & 92 & 2.73 & 1 \\
\hline Syria & 11 & 96 & 3.05 & 96 & 2.66 & 0 \\
\hline Algeria & 12 & 103 & 2.82 & 105 & 2.41 & 2 \\
\hline Yemen & 13 & 127 & 1.72 & 127 & 1.49 & 0 \\
\hline Comoro Island & 14 & 128 & 1.67 & 130 & 1.44 & 2 \\
\hline Djibouti & 15 & 129 & 1.66 & 124 & 1.56 & -5 \\
\hline Mauritania & 16 & 131 & 1.58 & 126 & 1.50 & \\
\hline Average & & 3.57 & & 3.04 & -5 \\
\hline
\end{tabular}

Source: International Telecommunication Union (ITU) Report, 2011.

Table 5. Fixed-telephone cost, 2008 and 2010

\begin{tabular}{|c|c|c|c|c|c|}
\hline \multirow[t]{2}{*}{ Country } & \multicolumn{2}{|c|}{$\begin{array}{l}\text { Fixed-telephone sub-basket as \% of } \\
\text { GNI capita }\end{array}$} & \multirow[t]{2}{*}{ Value change } & \multirow[t]{2}{*}{ Regional Rank } & \multirow{2}{*}{$\begin{array}{l}\text { Global rank }(165 \\
\text { countries) }\end{array}$} \\
\hline & 2008 & 2010 & & & \\
\hline UAE & 0.1 & 0.1 & 0.0 & 1 & 2 \\
\hline Bahrain & 0.2 & 0.2 & 0.0 & 2 & 5 \\
\hline Saudi Arabia & 0.6 & 0.6 & 0.0 & 3 & 28 \\
\hline Syria & NA & 0.6 & NA & 4 & 29 \\
\hline Tunisia & 1.0 & 0.8 & -0.2 & 5 & 38 \\
\hline Oman & 0.7 & 0.9 & 0.2 & 6 & 44 \\
\hline Qatar & 0.9 & 0.9 & 0.0 & 7 & 45 \\
\hline Yemen & 1.0 & 1.2 & 0.2 & 8 & 57 \\
\hline Algeria & 1.3 & 1.5 & 0.2 & 9 & 69 \\
\hline Lebanon & 1.8 & 1.5 & -0.2 & 10 & 75 \\
\hline Egypt & 2.0 & 1.7 & -0.3 & 11 & 79 \\
\hline Jordan & 3.1 & 2.9 & -0.2 & 12 & 104 \\
\hline Djibouti & 8.1 & 7.7 & -0.3 & 13 & 135 \\
\hline Morocco & 11.1 & 9.2 & -1.8 & 14 & 140 \\
\hline Comoros & 17.9 & 13.8 & -4.1 & 15 & 142 \\
\hline Maurit ania & 18.2 & 22.5 & 4.3 & 16 & 155 \\
\hline
\end{tabular}

Source: International Telecommunication Union (ITU) Report, 2011.

\subsection{Fixed-Telephone}

Data of fixed-telephone sub-basket are presented in Table 5. The sub-basket for 2010 includes the price of the monthly subscription plus 30 local calls - half peak time and half off-peak time - of three minutes each[7]. In 2008, the average fixed-telephone sub-basket for the Arab countries corresponds to 4.2 per cent of monthly GNI per capita as compared to 4.1 in 2010 , reflecting a decrease of 0.1 per cent.

Three of the top five countries with lowest fixed-telephone sub-basket tariffs are members of the GCC countries with high-inco me economics, these countries are UAE, Bahrain, and Saudi Arabia. Syria and Tunisia came in the fourth and fifth position respectively despite being among the moderate income countries compared to Qatar and Oman which came in the sixth and seventh order.
Meanwhile the top five countries with expensive fixed-telephone tariffs in the Arab world are found in the low-income countries. These are Mauritania, Comoros, Morocco, Djibouti, and Jordan. It should be noted that, the above five countries, except Mauritania, reported a decrease of fixed-telephone price between 0.2 to 4.1 per cent in 2010 compared to 2008, while Mauritania witnessed an increase of 4.3 per cent. Six countries have moderate fixed-telephone tariffs. The tariffs for three of these countries, Oman, Yemen, and Algeria, reported an increase of 0.2 per cent in 2010 , while the tariffs were decreased by 0.2 per cent in Lebanon and 0.3 per cent in Egypt in 2010. The tariff remained stable for Qatar in 2010.

\subsection{Mobile-Cellul ar}

Data of mobile-cellular sub-basket are presented in Table 
6. The sub-basket for 2010 includes the price of 30 outgoing calls for peak, off-peak and weekend periods and to the same and other mobile and fixed networks plus 100 SMS[7]. In 2008, the average mobile-cellular sub-basket for the Arab countries was 8.1 per cent of the monthly GNI per capita as compared to 7.5 in 2010 . This means that the mobile-cellular sub-basket costs decreased in 2010 by an average of 0.6 per cent as compared with 2008 .

GCC countries appeared on the top of Table 6 with lowest mobile-cellular sub-basket cost. However, Qatar is the only GCC country which increased mobile-cellular sub-basket tariffs from 1.7 per cent in 2008 to 1.8 per cent in 2010. Meanwhile the most expensive mobile-cellular tariffs countries in the Arab world are found in the low-income countries, specifically Comoros, Mauritania, Morocco, Djibouti, and Syria. It should be noted that, all these countries, except Djibouti, reported a decrease of mob ile cost between 2.8 to 9.8 per cent in 2010. While Djibouti, in 2010, witnessed an increase of 0.9 per cent. The remaining six countries, Jordan, Tunisia, Algeria, Lebanon, Egypt, and Yemen, have moderate mobile costs. These countries reported a decrease of mobile tariffs between 0.3 per cent to 1.8 per cent in 2010 co mpared to 2008 figures.

Table 6. Mobile-cellular cost, 2008 and 2010

\begin{tabular}{|c|c|c|c|c|c|}
\hline \multirow{2}{*}{ Country } & \multicolumn{2}{|c|}{$\begin{array}{c}\text { Mobile } \\
\text { Cellular su b- } \\
\text { basket as \% of } \\
\text { GNI capita }\end{array}$} & $\begin{array}{c}\text { Value } \\
\text { change }\end{array}$ & $\begin{array}{c}\text { Regional } \\
\text { Rank }\end{array}$ & $\begin{array}{c}\text { Global } \\
\text { rank (165 } \\
\text { countries) }\end{array}$ \\
\cline { 2 - 4 } & 2008 & 2010 & & & \\
\hline UAE & 0.1 & 0.1 & 0.0 & 1 & 2 \\
\hline Oman & 0.7 & 0.6 & -0.1 & 2 & 17 \\
\hline Bahrain & 0.7 & 0.7 & 0.0 & 3 & 20 \\
\hline Saudi & 1.1 & 1.0 & -0.1 & 4 & 27 \\
Arabia & 1.7 & 1.8 & 0.1 & 5 & 54 \\
\hline Qatar & 1.7 & 3.2 & -0.3 & 6 & 80 \\
\hline Jordan & 3.4 & 3.2 & -1.1 & 7 & 82 \\
\hline Tunisia & 4.3 & 3.2 & 8 & 86 \\
\hline Algeria & 4.4 & 3.4 & -2.2 & 8 & 95 \\
\hline Lebanon & 5.7 & 4.1 & -1.6 & 9 & 96 \\
\hline Egypt & 5.6 & 4.1 & -1.6 & 10 & 127 \\
\hline Yemen & 11.0 & 9.2 & -1.8 & 11 & 129 \\
\hline Syria & NA & 9.9 & NA & 12 & 139 \\
\hline Djibouti & 13.1 & 14.0 & 0.9 & 13 & 140 \\
\hline Morocco & 17.2 & 14.3 & -2.8 & 14 & 147 \\
\hline Mauritania & 18.6 & 18.3 & -0.3 & 15 & 156 \\
\hline Comoros & 43.2 & 33.5 & -9.8 & 16 & \\
\hline
\end{tabular}

Source: International Telecommunication Union (ITU) Report, 2011.

\subsection{Fixed Broadband}

Data for the fixed Broadband sub-basket are presented in Table 7. In 2008, the average broadband sub-basket for the Arab countries corresponds to 75.4 per cent of monthly GNI per capita as compared to 49.9 in 2010 . This means the fixed broadband sub-basket decreased in 2010 by an average of 25.5 per cent as compared with 2008.

Four of the top five countries with lowest fixed broadband sub-basket are members of the GCC countries which have high-income economics. These countries are UAE, Bahrain,
Saudi Arabia, and Oman. Tunisia came in the fifth position despite being among the moderate income countries compared to Qatar which took the tenth position among sixteen Arab countries.

Meanwhile, the most expensive fixed broadband tariffs countries in the Arab world are Comoros, Yemen, Djibouti, Mauritania, and Syria. It should be noted that, the last five countries registered decrease of fixed broadband tariffs, in 2010, between 47.7 to 156.4 per cent. Five countries with a moderate tariff price; Lebanon, Algeria, Egypt, Morocco, and Jordan; registered a decrease of fixed broadband between 0.6 to 4.1 per cent in 2010. Again, the tariff remains stable for Qatar with no change from 2008 to 2010.

Table 7. Fixed Broadband, 2008 and 2010

\begin{tabular}{|c|c|c|c|c|c|}
\hline \multirow{2}{*}{ Country } & \multicolumn{2}{|c|}{$\begin{array}{c}\text { Fixed } \\
\text { broadband } \\
\text { sub-basket as \% } \\
\text { of GNI capita }\end{array}$} & $\begin{array}{c}\text { Value } \\
\text { change }\end{array}$ & $\begin{array}{c}\text { Regional } \\
\text { Rank }\end{array}$ & $\begin{array}{c}\text { Global } \\
\text { rank (165 } \\
\text { countries) }\end{array}$ \\
\cline { 2 - 4 } & 2008 & 2010 & & 1 & 22 \\
\hline UAE & 0.8 & 0.8 & 0.0 & 2 & 35 \\
\hline Bahrain & 1.3 & 1.3 & 0.0 & 2 & 46 \\
\hline $\begin{array}{c}\text { Saudi } \\
\text { Arabia }\end{array}$ & 2.7 & 1.8 & -0.9 & 3 & 51 \\
\hline Oman & 2.1 & 2.1 & 0.0 & 4 & 70 \\
\hline Tunisia & 4.1 & 3.1 & -0.7 & 5 & 71 \\
\hline Lebanon & 4.0 & 3.4 & -0.6 & 6 & 76 \\
\hline Algeria & 4.8 & 4.0 & -0.8 & 7 & 79 \\
\hline Egypt & 5.5 & 4.6 & -0.9 & 8 & 84 \\
\hline Morocco & 9.2 & 5.1 & -4.1 & 9 & 85 \\
\hline Qatar & 5.5 & 5.5 & 0.0 & 10 & 88 \\
\hline Jordan & 6.7 & 5.7 & -1.0 & 11 & 104 \\
\hline Syria & NA & 10.8 & NA & 12 & 123 \\
\hline Mauritania & 77.1 & 29.4 & -47.7 & 13 & 134 \\
\hline Djibouti & 111.6 & 52.3 & -59.3 & 14 & 134 \\
\hline Yemen & 281.6 & 134.9 & -146.7 & 15 & 147 \\
\hline Comoros & 690.8 & 534.5 & -156.3 & 16 & 160 \\
\hline Source
\end{tabular}

Source: International Telecommunication Union (ITU) Report, 2011.

\subsection{ICT Price Basket}

Table 8 presents the averages and standard deviations of the ICT Price Basket (IPB) index among different sub-regions of the Arab countries. This table shows very clear differences in the ICT prices among the different sub-regions. Specifically, the table indicates that the price of ICT services in the GCC sub-region is the lowest, with an average of 1.2. The average of prices dramatically increased to reach 8.4 for Magreb countries, 12.5 for Levant countries, and 36.9 for the other Arab countries. On the hand, the standard deviation of the GCC countries is very small (0.88713) compared to the other Arab sub-regions. This indicates that there are no significant differences among the GCC countries in regards to the cost of ICT services. In contrast, high standard deviations, which reached up to 17.25341 for the other Arab sub-regions reveal significant differences among the countries in these sub-regions. Regionally, this may indicates that telecommunication and Internet services in the Arab countries are becoming more 
affordable.

Table 8. Means and Standard deviations of IDI index of the Arab countries in the different sub-regions

\begin{tabular}{|c|c|c|c|}
\hline Sub-region & $\mathbf{N}$ & Mean & Std. De viation \\
\hline GCC & 5 & 1.2200 & .88713 \\
\hline LEVANT & 4 & 12.5000 & 15.76515 \\
\hline MAGREB & 5 & 8.4000 & 8.86595 \\
\hline OTHERS & 2 & 36.9000 & 17.25341 \\
\hline Total & 16 & 10.7438 & 14.65715 \\
\hline
\end{tabular}

\subsection{ICT De vel opment Index}

The ICT Development Index (IDI) in the Arab countries has significantly increased for the year 2010 as compared with the year 2008 as shown in Figure 1. The very small p-value in Table 9.b which presents the paired samples t-test ( $p$ value $<0.05$ ) confirms this result as shown in Table 9.a. This table shows that the average of IDI in 2008 (3.034) is significantly different from the average of the IDI in 2010 (3.565) for the Arab countries. Figure 1 confirms this result which shows that the IDI index in the GCC countries is much higher than that in the rest of the Arab countries.

Table 9a. Paired Samples Statistics

\begin{tabular}{|c|c|c|c|c|c|}
\hline \multicolumn{2}{|c|}{} & Mean & $\mathrm{N}$ & $\begin{array}{c}\text { Std. } \\
\text { Deviation }\end{array}$ & $\begin{array}{c}\text { Std. Error } \\
\text { Mean }\end{array}$ \\
\hline \multirow{3}{*}{ Pair 1 } & $\begin{array}{c}\text { ICT Development } \\
\text { Index (IDI) 2008 }\end{array}$ & 3.0344 & 16 & 1.29655 & .32414 \\
\cline { 2 - 6 } & IDI 2010 & 3.5650 & 16 & 1.52282 & .38070 \\
\hline
\end{tabular}

Table 9b. Paired Samples Correlations

\begin{tabular}{|c|c|c|c|c|}
\hline \multicolumn{2}{|c|}{} & $\mathrm{N}$ & Correlation & Sig. \\
\hline Pair 1 & $\begin{array}{c}\text { ICT Development Index } \\
\text { (IDI) 2008 \& IDI_2010 }\end{array}$ & 16 & .983 & .000 \\
\hline
\end{tabular}

Clearly there is an important heterogeneity in the ICT development across the Arab countries. Further analysis shows that high-income countries are as sociated with higher intensity level of ICT Development. For example, the IDI level for UAE is 6.19, while this level is around 5.5 for Qatar, Bahrain, and Saudi Arabia. Levant region itself reflects different patterns of diffusion, both between and within countries. Sub-regionally, Lebanon shows higher level of ICT Development than the other non-Gulf countries (see Figure 1). For instance, considering the ITU's ICT Develop ment Index (IDI) ranks presented in Table 4, Jordan and Lebanon are the better ranked of the Levant countries in 2010 (ranking 73 and 79 respectively), while Yemen is by far the worst ranked (127) after Syria 96.

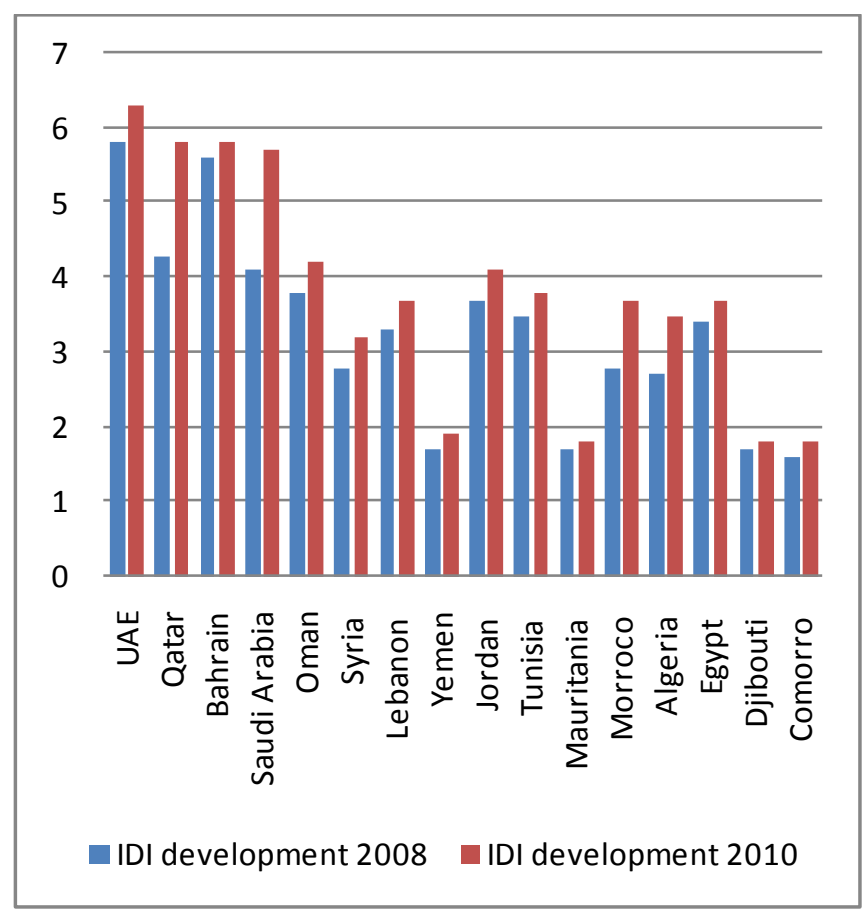

Figure 1. IDI in 2008 and 2010

Table 10. Multiple Comparisons of IDI using T ukey method

\begin{tabular}{|c|c|c|c|c|c|c|}
\hline \multirow{2}{*}{$\begin{array}{c}\text { (I) } \\
\text { BLOCK }\end{array}$} & \multirow{2}{*}{ (J) BLOC K } & \multirow{2}{*}{ Mean Difference (I-J) } & \multirow{2}{*}{ Std. Error } & \multirow{2}{*}{ Sig. } & \multicolumn{2}{|c|}{ 95\% Con fidence In terval } \\
\hline & & & & & Lower Bound & Upper Bound \\
\hline \multirow{3}{*}{ GCC } & LEVANT & $2.39200^{*}$ & .50027 & .002 & .9068 & 3.8772 \\
\hline & MAGREB & $2.55400^{*}$ & .47166 & .001 & 1.1537 & 3.9543 \\
\hline & OT HER & $3.76700^{*}$ & .62394 & .000 & 1.9146 & 5.6194 \\
\hline \multirow{3}{*}{ LEVANT } & GCC & $-2.39200^{*}$ & .50027 & .002 & -3.8772 & -.9068 \\
\hline & MAGREB & .16200 & .50027 & .988 & -1.3232 & 1.6472 \\
\hline & OT HER & 1.37500 & .64584 & .199 & -.5424 & 3.2924 \\
\hline \multirow{3}{*}{ MAGREB } & GCC & $-2.55400^{*}$ & .47166 & .001 & -3.9543 & -1.1537 \\
\hline & LEVANT & -.16200 & .50027 & .988 & -1.6472 & 1.3232 \\
\hline & OTHER & 1.21300 & .62394 & .262 & -.6394 & 3.0654 \\
\hline \multirow{3}{*}{ OTHER } & GCC & $-3.76700^{*}$ & .62394 & .000 & -5.6194 & -1.9146 \\
\hline & LEVANT & -1.37500 & .64584 & .199 & -3.2924 & .5424 \\
\hline & MAGREB & -1.21300 & .62394 & .262 & -3.0654 & .6394 \\
\hline
\end{tabular}

*The mean difference is significant at the 0.05 level. 
The multiple comparison results of the PostHoc test, presented in Table 10, shows significant differences among the averages of IDI index of at least two sub-regions of countries in the Arab world. According to these results ( $p$ value $<0.05)$, there is a statistical significance in the level of ICT access and use in the GCC sub-region and each one of the other Arab sub-regions.

\subsection{Relationship between IDI and IPB}

A comparis on of the IPB prices with the IDI index of the Arab countries, presented in Figure 2, shows that countries with relatively high ICT Development Index (IDI) have relatively low level of ICT access and use. These results is in line with the ITU findings [7]. The year 2010's IPB figures of the Arab region reveal a close link between the affordability of ICT services and national income levels. People of the high-inco me countries pay relatively little for the ICT services; wh ile those in the world's poorest countries pay relatively more. Figure 3 shows that people living in the GCC countries pay the lowest prices for the ICT services. There are almost moderate prices in the Levant and Magreb sub-regions except for Yemen and Mauritania. In the sub-region of the other Arab countries, mainly Djibouti and Comoro Island, the prices are so expensive to reach as high as USD50 co mpared to USD2 for the GCC sub-region.

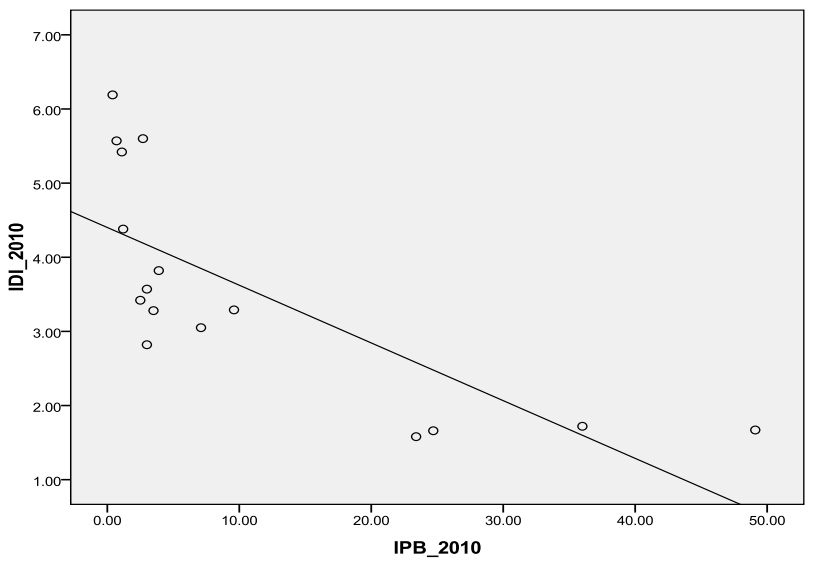

Figure 2. Relationship between ICT Development Index (IDI) and ICT Price Basket(IPB)

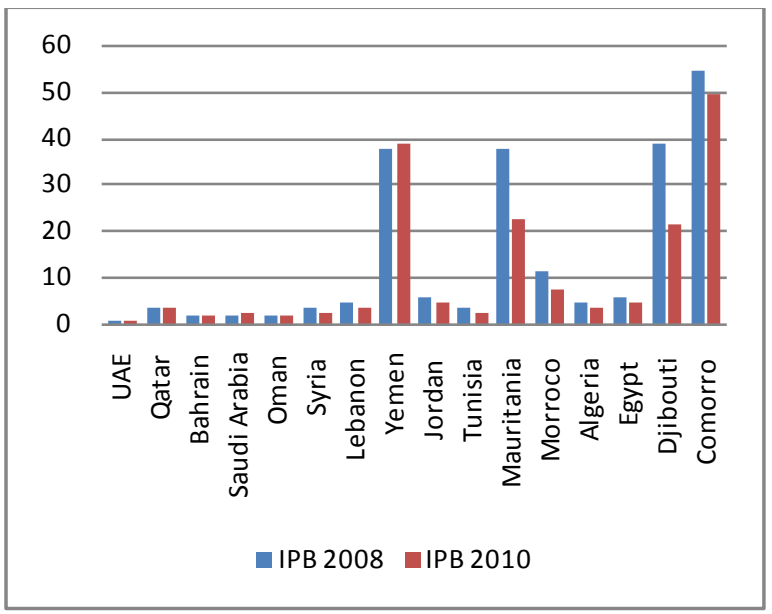

Figure 3. IPB in 2008 and 2010
For further investigation, we performed analysis of variance to find out the differences among different Arab sub-regions (GCC, Levant, Magreb and the other Arab countries). The ANOVA table (Table 11) shows that significant differences exist among different sub-regions of the Arab world in the ICT Development Index as well as in the IPB price basket, with $\mathrm{p}$ value $<0.05$.

Table 11. ANOVATable for IDI and IPB

\begin{tabular}{|c|c|c|c|c|c|c|}
\hline \multicolumn{2}{|c|}{} & $\begin{array}{c}\text { Sum of } \\
\text { Squares }\end{array}$ & Df & $\begin{array}{c}\text { Mean } \\
\text { Square }\end{array}$ & F & Sig. \\
\hline \multirow{5}{*}{ IDI_2010 } & $\begin{array}{c}\text { Between } \\
\text { Groups }\end{array}$ & 28.111 & 3 & 9.370 & 16.848 & .000 \\
\cline { 2 - 7 } & $\begin{array}{c}\text { Within } \\
\text { Groups }\end{array}$ & 6.674 & 12 & .556 & & \\
\cline { 2 - 8 } & Total & 34.785 & 15 & & & \\
\hline \multirow{5}{*}{ IPB_2010 } & $\begin{array}{c}\text { Between } \\
\text { Groups }\end{array}$ & 1861.611 & 3 & 620.537 & 5.472 & .013 \\
\cline { 2 - 8 } & $\begin{array}{c}\text { Within } \\
\text { Groups }\end{array}$ & 1360.868 & 12 & 113.406 & & \\
\cline { 2 - 8 } & Total & 3222.479 & 15 & & & \\
\hline
\end{tabular}

\subsection{Relationship between GNI and IDI}

As shown in Figure 4, there is a strong relationship between Gross National Income (GNI) and ICT Development Index (IDI). The Pearson correlation coefficient $(r=0.78)$ confirms this result. This indicates that a high GNI for a country will result in a high ICT Development Index; while the low GNI for a country will result in low ICT Development Index.

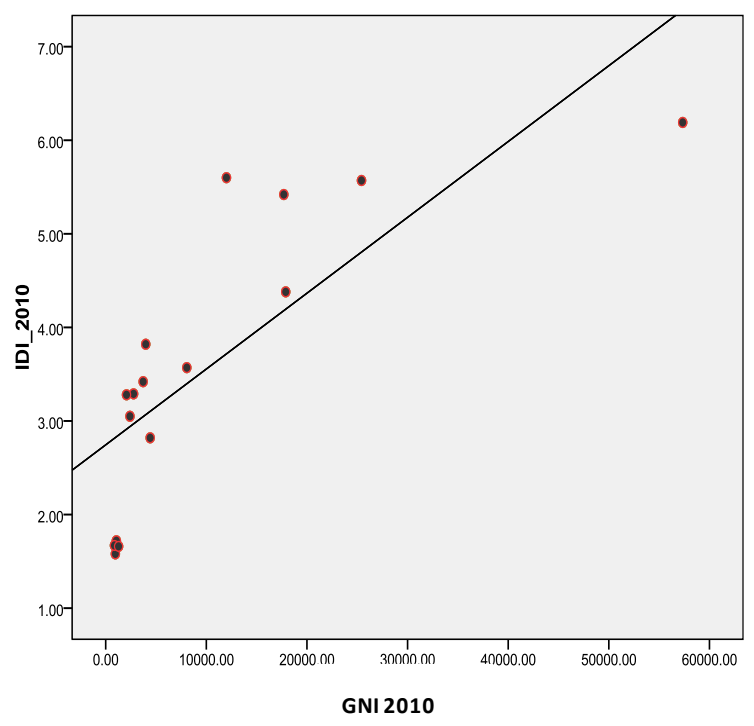

Figure 4. IDI and GNI, 2010

\section{Conclusions}

Based on the ITU data[7] used in this study, our findings prove that the Arab countries have achieved, in 2010, a significant progress towards developing information society. This progress can easily be noticed in the GCC countries than the rest of Arab countries. Similarly, results of the study 
found significant differences among the Arab countries in regard to the ICT Price Basket (IPB). The average of the price for the ICT services in the GCC countries is the lowest, in 2010, as compared to the other Arab countries. This might be because the GCC countries have strong economic and better ICT development strategies than the other Arab countries. Findings of the study show a relationship between ICT Development Index (IDI) and ICT Price Basket (IPB). That means countries with relatively high ICT cost have relatively low levels of ICT access and use. These findings are in line with the ITU report in 2011[7]. Similarly, the analysis of the study found a strong relationship between Gross National Income (GNI) and ICT Development Index (IDI), which means a high GNI for a country will result in a high ICT Development Index; and vice versa.

Finally, since this study is based on ICT, IPB and GNI indicators, there is a need for conducting further studies to include more indicators in measuring information society of the Arab countries.

\section{REFERENCES}

[1] Ramachandran Ramasamy, "Benchmarking Malaysia in the global information society: regressing or progressing?" Journal of Centrum Cathedra, vol. 3, no. 1, pp. 67-83, 2010.

[2] Fritz Machlup "The production and distribution of knowledge in the United States", Princeton University Press, Princeton, NJ, 1962.

[3] Lena Tsipouri, "Europe and the information society: problems and challenges for supranatioanl intervention", Journal of Comparative Policy Analysis, vol. 2, no. 3, pp.
301-319, 2000.

[4] Benjamin J. Bates "Conceptualizing the information society: the search for a definition of social attributes" Paperpresented at the 34th International Communication Association Conference, San Fran cisco, CA, May 1984. Online Availab le: www.cci.utk.edu/ bates/papers/bates-concept-is.pdf

[5] Frank Webster "The Information Society Revisited", in Sonia Livingstone and Leah Lievrouw (ed.), "Handbook of New Media: Social Shaping and Consequences of ICTs", Sage, London, pp. 23-33, 2002.

[6] László Z. Karvalics "Information society-what is it exactly? The meaning, history and conceptual framework of an expression", in L D. Vinci (ed.), "Society: from theory to political practice," Network for Teaching Information society (NETIS), Budapest, pp. 1-26, 2007.

[7] International Telecommunication Union (ITU). (2011). Measuring Information Society 2011. International Telecommunication Union (ITU), Geneva, Switzerland, 2011. Online Available:

[8] http://www.itu.int/ITU-D/ict/publications/idi/2011/index.htm 1

[9] Neil McBride, Bernd Carsten Stahl. Egypt's information society strategy: a critical lexicography. Journal of International Technology and Information Management, vol. 18 , no. 1 , pp. 1-33, 2009.

[10] David Morgan, "Towards information society-National e-strategies in the Arab world", 2010. Online available: http://www.y acout.info/Towards-Information-Society-Natio nal-e-Strategies-in-the-Arab-World_a1422.html

[11] Fahad Abdullah Al Sudairy, "Impact of ICT on economy and society and quality of life: gulf Cooperation Council region (GCC)", 2010. Online Available: http://www.stsforum.org/P revious/2010/PL_speach/PL204A_AlSudairy.pdf 